\title{
A Research on Employee Involvement in Pharmaceutical Industry in India
}

\author{
D. Rajasekar, A.Krishna Sudheer
}

\begin{abstract}
Any industrial growth depends upon the involvement of its employees. Every employee is the backbone of the organization.to find out clear information many researchers have found many ways in terms of issuing questionnaires and primary information, for this study the researcher has considered some 477 samples from them have got conclusion and stating that many have involved in the industry for this study the researcher has taken stratified sampling using different statistical tools. And there is a significant relationships with employee involvement.
\end{abstract}

Key words: Industry, Involvement, stratified sampling, relationships etc...

\section{INTRODUCTION}

Orchid Chemicals \& Pharmaceuticals Limited is a publicly quoted pharmaceutical company engaged in the application of development, manufacture, sale, and export of active pharmaceuticals contains and finished dosage forms or formulations. The company is publicly traded on the Bombay Stock Exchange under the trading symbol.The Company is mainly engaged in a one pharmaceutical major with diversified competencies in bulk drugs, formulations and drug discovery, with a strong orientation towards the advanced regulated markets. The Company was founded in 1992 Orchid has been recognized as the only company in the Indian Pharmaceutical industry to have recorded remarkable growth in a decade of operations. Employee involvement was revolutionized when McGregor (1957) and Hertzberg (1966) first started writing about the topic in their articles "The Human Side of Enterprise" and "Work and the Nature of Man". Lawler et al. (1992) discussed the subject under four topics (practices) - (i) information sharing, (ii) knowledge and training, (iii) rewards and (iv) power sharing.

\section{REVIEW OF LITERATURE:}

Kuye and Sulaimon (2011) examined the relationship between employee involvement in decision making and firms' performance in the manufacturing sector in Nigeria. Data were gathered by means of questionnaires from 670 manufacturing firms on employee involvement in decision making and performance variables. It revealed a significant difference between the performance of firms whose employee involvement in decision making are deep and the performance of firm's whose employee involvement in decision making are shallow. The findings also revealed the involvement of participating firms in employee involvement in decision making..
Revised Manuscript Received on April 12, 2019.

Dr.D.Rajasekar,Professor, AMET Business School, AMET University, Chennai, Tamilnadu, India.

Dr.A.KrishnaSudheer, Professor\&Head of MBA, AMET Business School, AMET University, Chennai, Tamilnadu, India
Ekmekci (2011) conducted a study aimed to explore the relationship between employee's involvement and their feeling of organizational commitment among the employees working at two multinational companies in Turkey. The study also examined the demographic factors in terms of their impact on the relationship between employee involvement and organizational commitment, and found no statistical significant relationship.

Abutayeh and Manar (2012) examined the effect of Human Resource Practices on employee involvement in an Arabic country (Jordan) by considering six of the major Human Resource Practices, Results showed that all human resource practices have a positive effect on employee involvement, where selection exhibited highest effect and training had the lowest effect.

Poongavanam et.al (2018) explained that in a company where all employees and group of people work together and achieving common goal, and sometimes difference of opinion may arise and there by grievances, employee angers and so on. Finally it is stated that employees are remain in their works and involving their routine work.

\section{NEED FOR THE STUDY:}

previous studies have focused on relationships between employee involvement or empowerment and job satisfaction. But, none of the researcher was taken up involvement in pharmaceutical company. Very few Studies have focused on the influence of demographic factors on employee involvement.

\section{OBJECTIVES OF THE STUDY:}

1. To find out the influence of demographic characteristics on employee involvement.

2. To suggest a comprehensive model combining the various factors of employee involvement

\section{Hypothesis:}

H1: There is a significant difference between male and female employees in their perception toward employee involvement,

H1a: There is significant relationship between gender and employee involvement.

H2: There is significant difference among employees of varied age in their perception towards involvement,

$\mathrm{H} 2 \mathrm{a}$ : There is significant relationship between age and employee involvement. 
A Research On Employee Involvement In Pharmaceutical Industry In India

Sources of Measurement Scales Used in

\begin{tabular}{|l|c|c|c|c|c|c|c|}
\hline \multicolumn{8}{|c|}{ Table 1:Knowledge (scale) frequency distribution } \\
\hline Scales (Knowledge) & $\mathbf{1}$ & $\mathbf{2}$ & $\mathbf{3}$ & $\mathbf{4}$ & $\mathbf{5}$ & Mean & S.D. \\
\hline $\begin{array}{l}1 . \\
\text { I have taken sufficient } \\
\text { training to do my job. }\end{array}$ & 9 & 15 & 60 & 243 & 150 & 4.07 & 0.856 \\
\hline $\begin{array}{l}2 . \\
\text { I have been given a real } \\
\text { opportunity to improve my } \\
\text { skills in my company. }\end{array}$ & 18 & 42 & 81 & 210 & 126 & 3.81 & 1.044 \\
\hline $\begin{array}{l}3 . \\
\begin{array}{l}\text { My supervisor helps me } \\
\text { obtain the developmental } \\
\text { experiences I need to do my } \\
\text { job well. }\end{array}\end{array}$ & 30 & 3 & 111 & 204 & 129 & 3.84 & 1.034 \\
\hline $\begin{array}{l}\text { I received the needed } \\
\text { coaching and feedback about } \\
\text { my performance. }\end{array}$ & 30 & 27 & 54 & 219 & 147 & 3.90 & 0.700 \\
\hline
\end{tabular}

From the table 1, 31.4\% (150) of respondents are strongly agreed and $50.94 \%$ (243) were agreed with the statement "I have taken sufficient training to do my job". Only $1.8 \%$ (9) was strongly disagreed with the mentioned statement. Thus, a mean of 4.07 was recorded for the statement. For the statement "I am given a real opportunity to improve my skills in my company", $26.4 \%$ have strongly agreed and 44 $\%$ have agreed, recording a mean value of 3.81. For the statement regarding the supervisor help and support, $27 \%$ have strongly agreed, $42.8 \%$ have agreed, $23.2 \%$ are neutral and $6.9 \%$ disagreed, recording a mean value of 3.84 . For the statement regarding the receiving of coaching and feedback, $30.8 \%$ have strongly agreed, $45.9 \%$ have agreed, $11.3 \%$ are neutral and $11.9 \%$ have disagreed, recording a mean score of 3.90 .

REWARDS that are purely based on the performance of the organization and that are prepared to encourage workers makes them to involve indecision-making responsibility, enhance teamwork, and perform in ways that help the business. Five item scales were considered in the study to examine the level of agreement of the respondents regarding their perception toward reward system in their organization.

\begin{tabular}{|c|c|c|c|c|c|c|c|}
\hline \multicolumn{8}{|c|}{ Table 2:Rewards (scale) frequency distribution } \\
\hline Scales (Rewards) & 1 & 2 & 3 & 4 & 5 & Mean & S.D. \\
\hline $\begin{array}{l}\text { 1. I am verysatisfied with the } \\
\text { amount of recognition I } \\
\text { receive when I do a good job }\end{array}$ & 30 & 39 & 90 & 219 & 99 & 3.67 & 1.087 \\
\hline $\begin{array}{l}\text { 2. Generally I feel this company } \\
\text { rewards employees who make } \\
\text { an extra effort }\end{array}$ & 60 & 36 & 99 & 192 & 90 & 3.45 & 1.239 \\
\hline $\begin{array}{l}\text { 3. There is a strong link between } \\
\text { how well I perform my job } \\
\text { and the likelihood of receiving } \\
\text { a raise in a pay/salary }\end{array}$ & 36 & 27 & 117 & 165 & 132 & 3.69 & 1.156 \\
\hline $\begin{array}{l}\text { 4. There is a strong link between } \\
\text { how well I perform my job } \\
\text { and the likelihood of receiving } \\
\text { high performance appraisal } \\
\text { ratings }\end{array}$ & 33 & 27 & 102 & 219 & 96 & 3.67 & 1.075 \\
\hline $\begin{array}{l}\text { 5. If I perform well, I am more } \\
\text { likely to be promoted. }\end{array}$ & 54 & 27 & 87 & 189 & 120 & 3.62 & 1.239 \\
\hline
\end{tabular}

From the table 2, 20\% (99) of respondents are strongly agreed and 6\% (30) strongly disagreed with the statement "I am satisfied with the amount of recognition I receive when I do a good job". Thus, a mean of 3.67 was recorded for this statement. For the statement "Generally I feel this company rewards employees who make an extra effort", 90 respondents were strongly disagreed and 60 were strongly agreed with a mean of 3.45 . For the statement "There is a strong link between how well I perform my job and the likelihood of receiving a raise in a pay/salary", strongly disagreed was 132 respondents and strongly agreed was 32 with a mean of 3.69. For the statement "If I perform well, I am more likely to be promoted", 120 respondents were strongly agreed and 54 respondents were strongly disagreed with a mean of 3.62 .

POWER, is another important variable, the table shows the clear information. 


\begin{tabular}{|c|c|c|c|c|c|c|c|}
\hline \multicolumn{8}{|c|}{ Table 3:Power (scale) frequency distribution } \\
\hline Scales (Power) & 1 & 2 & 3 & 4 & 5 & Mean & S.D. \\
\hline $\begin{array}{l}\text { 1. I have sufficient authority to } \\
\text { fulfill my job responsibilities. }\end{array}$ & 18 & 42 & 51 & 237 & 129 & 3.87 & 1.027 \\
\hline $\begin{array}{l}\text { 2. I have given more freedom on } \\
\text { my job }\end{array}$ & 21 & 42 & 81 & 213 & 120 & 3.77 & 1.059 \\
\hline $\begin{array}{l}\text { 3. I have more freedom over how } \\
\text { I do my job. }\end{array}$ & 54 & 33 & 96 & 201 & 93 & 3.52 & 1.208 \\
\hline $\begin{array}{l}\text { 4. I have given more } \\
\text { encouragement in an } \\
\text { organization. }\end{array}$ & 21 & 18 & 93 & 201 & 144 & 3.90 & 1.018 \\
\hline
\end{tabular}

From the table $\mathbf{3}$, the four scale items used in the survey has recorded a mean value with a range of 3.5 to 3.9. For the first statement "I have sufficient authority to fulfil my job responsibilities", 129 respondents were strongly agreed and 237 were agreed, whereas 60 respondents were shown disagreement. For the second statement "I have given more freedom on my job $69.8 \%$ (333) have shown the agreement and $13.2 \%$ (63) have shown the disagreement. The third statement "I have morefreedom over how I perform my job" has shown a least mean value of 3.52 and the final statement "I have given good encouragement in the organisation a high mean value of 3.90 in the "Power" scale items.

INFORMATION sharing is about business performance, plans, goals, and strategies, to know the level of agreement of the respondents, six scales were used which are listed as shown in the table 5.14.

\begin{tabular}{|c|c|c|c|c|c|c|c|}
\hline \multicolumn{8}{|c|}{ Table 4:Information (scale) frequency distribution } \\
\hline Scales (Information) & 1 & 2 & 3 & 4 & 5 & Mean & S.D. \\
\hline $\begin{array}{l}\text { 1. Company aims and goals are } \\
\text { clearly informedto employees }\end{array}$ & 33 & 27 & 84 & 228 & 105 & 3.72 & 1.082 \\
\hline $\begin{array}{l}\text { 2. The communication with top } \\
\text { management are effective }\end{array}$ & 45 & 27 & 84 & 195 & 126 & 3.69 & 1.193 \\
\hline $\begin{array}{l}\text { 3. Top management is adequately } \\
\text { informed of the important } \\
\text { issues in my department }\end{array}$ & 39 & 33 & 81 & 210 & 114 & 3.69 & 1.151 \\
\hline $\begin{array}{l}\text { 4. Company guidelines and } \\
\text { activities are clearly } \\
\text { communicated to employees }\end{array}$ & 33 & 21 & 96 & 219 & 108 & 3.73 & 1.075 \\
\hline $\begin{array}{l}\text { 5. I often have to be dependenton } \\
\text { the grapevine to get job-related } \\
\text { information (reverse) }\end{array}$ & 52 & 27 & 102 & 195 & 111 & 3.64 & 1.157 \\
\hline $\begin{array}{l}\text { Most of the time I receive } \\
\text { sufficient notice of changes } \\
\text { disturbing my work group }\end{array}$ & 39 & 18 & 111 & 195 & 114 & 3.69 & 1.123 \\
\hline
\end{tabular}

From the above table, it was noticed that a high mean value $(M=3.73)$ was recorded to the statement "Company guide lines and the various activities of the company are clearly communicated to employees" and a low mean value $(M=3.64)$ was recorded to the statement "I often have to be dependent on the grapevine to get job-related information" which is a reverse scored statement. For the statement "Company aims and goals are clearly informed to employees", $69.8 \%$ (333) were agreed and $12.5 \%$ (60) were disagreed. For the statements "The communication with top management are effective", "Top management is sufficiently informed of the important issues in my department", and "Most of the time I receive sufficient notice of changes disturbing my work group", a mean value of 3.69 was recorded.

\section{THE QUESTIONNAIRE\& RESULTS}

\begin{tabular}{|l|l|l|}
\hline $\begin{array}{l}\text { Variables for } \\
\text { the Study }\end{array}$ & Sources & Scales \\
\hline $\begin{array}{l}\text { Employee } \\
\text { Involvement }\end{array}$ & $\begin{array}{l}\text { Lawler (1996), } \\
\text { Rose (2005). }\end{array}$ & $\begin{array}{l}\text { Knowledge,Rew } \\
\text { ard,Power, } \\
\text { andInformation }\end{array}$ \\
\hline
\end{tabular}

A pilot study with a sample size of 60 responses was conducted before arriving at the final questionnaire. Reliability analysis (Cronbach's alpha) was applied to check the reliability of items used in initial questionnaire. Based on reliability analysis and feedback from respondents, the final questionnaire was prepared. 
Reliability Analysis for Pilot Study

\begin{tabular}{|l|c|c|}
\hline \multicolumn{1}{|c|}{$\begin{array}{c}\text { Scales used in the } \\
\text { study }\end{array}$} & $\begin{array}{c}\text { No. of } \\
\text { Items }\end{array}$ & $\begin{array}{c}\text { Cronbach'sAl } \\
\text { pha }\end{array}$ \\
\hline $\begin{array}{l}\text { EMPLOYEE } \\
\text { INVOLVEMENT }\end{array}$ & $\mathbf{1 9}$ & $\mathbf{0 . 8 9 7}$ \\
\hline Knowledge & 4 & 0.696 \\
\hline Reward & 5 & 0.827 \\
\hline Power & 4 & 0.701 \\
\hline Information & 6 & 0.640 \\
\hline
\end{tabular}

\section{CONCLUSION:}

Today, scenario many companies are looking for good numbers of employees with quality and good work culture, expecting the every employee is involved in the work. So that the company growth and country GDP will be very high if both are going well. This study emphasizes the fact that employees must be given importance in decision making, so every employee of the organization

\section{REFERENCES:}

1. Kuye, O.L. and Sulaimon, A.H.A. (2011), "Employee Involvement in Decision Making and Firms Performance in the Manufacturing Sector in Nigeria", Serbian Journal of Management, Vol. 6, No. 1, pp. 1-15.

2. Ekmekci, A.K. (2011), "A Study on Involvement and Commitment of Employees in Turkey", Journal of Public Administration and Policy Research, Vol. 3, No. 3, pp. 68-73.

3. Abutayeh Bandar, and Manar Al-Qatawneh (2012), "The Effect of Human Resource Management Practices on Job Involvement in Selected Private Companies in Jordan”,Canadian Social Science Vol. 8, No. 2, 2012, pp. 50 57.

4. Preeti Thakur (2014) A Research Paper on the Effect of Employee Engagement on Job Satisfaction in IT Sector. Journal of Business Management \& Social Sciences Research (JBM\&SSR) ISSN No: 2319-5614 Volume 3, No.5, May 2014.

5. Poongavanam (2018): Impact of salary and reward on the achievement in the Pharma companies .Indian journal of Public health research and development.

6. Vettriselvan R., Ruben Anto., \&JesuRajan FSA (2018), Rural lighting for energy conservations and sustainable development, International Journal of Mechanical Engineering and Technology, 9(7):604-611.

7. Vettriselvan R., \& Ruben Anto., (2018) Pathetic Health Status and Working Condition of Zambian Women, Indian Journal of Public Health Research \& Development, 9(9):259-264.

8. Vettriselvan R., Sathya M., \&Velmurugan T. (2018), Productivity and Profitability Mechanical Engineering Entrepreneurs: Business Perspective, International Journal of Mechanical Engineering and Technology,9(8): 758-765.

\section{AUTHORS PROFILE:}

Dr.D.Rajasekhar, Professor, AMET

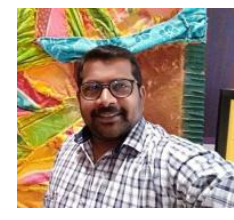
Business School, AMET University, Chennai, Tamilnadu, India, having 20 Years of experience and presented 50national and international conference pares and also published 100 journals in various Scopus indexed also, apart from he is guiding 15 $\mathrm{PhD}$ and produced 5 doctorates in his cap.rajamet3180@gmail.com

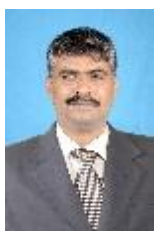

Dr.A.KrishnaSudheer,Prof\& Head of MBA in G.Pullaiah college of Engineering \&Technology, Kurnool, Andhra Pradesh, India, having 22 years of academic experience and presented 20papers in National and international conferences also published 23 research papers which includes 9 Scopus indexed journals, also having good exposure in Marketing , Humanresourses, and finance 